\title{
Appropriating the Ethos of Confucius for the Rebuilding of the Nigerian Commonwealth
}

\author{
Emmanuel Williams Udoh \\ Department of Religious and Cultural Studies \\ University Of Calabar, Cross River State, Nigeria. \\ Email: revemmaudoh@yahoo.com
}

(Received: May-2020; Reviewed: July-2020; Accepted: July-2020;

Avalaible Online: July-2020; Published: August-2020)

(c) (5) This is an open access article distributed under the Creative Commons Attribution License

EY CC-BY-NC-4.0 (2020 by author (https://creativecommons.org/licenses/by-nc/4.0/)

\begin{abstract}
The Nigerian commonwealth has been bastardized by our national political and economic managers. This has given rise to the current cry in search of unity, peace and patriotism of Nigerians. It can be said again that things have fallen apart and the centre seems not to hold any longer. The current wave of corruption, bloodshed, ethnic militia and communal and political subdivisions and carpet crossing at our political arena are clear signs of the deteriorating state of our Nigerian commonwealth. Good Nigerians desire to see Nigeria return back to her former glory of oneness, prosperity and pride. That is why this research explored the ethos of Confucius for the rebuilding of the Nigerian commonwealth. This work which is anchored on the sociological theory of "Structural Functionalism" propounded by Emile Durkheim (1850-1917) and adopted the qualitative or exploratory research method in gathering information. It employed the content analysis approach in examining available printed materials on the subject matter. The findings from the research showed that Nigerians have deviated from the ethical values that had initially been the source of strength and toe the path of selfishness, ethnicity and division. This new path became a path to corruption and disintegration. The research recommends an inclusiveness of human responsibility for improving life; adoption of an ideal political system founded on "ideals of personal conduct" rather than on formerly enacted laws; and adoption of a viable religious ethos that will revitalize the ailing economic, social and political status of the Nigerian commonwealth.
\end{abstract}

Keywords: Confucius; Ethos; Political; Religious; Commonwealth

\section{INTRODUCTION}

Nigeria being a country that is divinely blessed with both material and human resources has become a laughing stock for other nations, even in Africa (Eyo \& Ogar 2014; Ikegbu et al., 2009). It was a country that was respected because of its size, economy and strength. As the most populous country in Africa, she is noted for her advancement in technology, agriculture and other sectors of the economy. Nigeria also has earned the title of being the lion of Africa because of her role in fighting oppression, participation in peace missions in Africa and other 
parts of the world and in various other areas. She has assisted other African countries through peace keeping missions, political arrangements, educational infrastructure and manpower development. Nigeria had earned the respect of other nations of the world due to its determination to co-exist in unity and peace.

In recent times Nigeria has become plague with bad leadership, politics of tribalism, ethnicity and bitterness (Alumuna et al., 2017; Edet 2017). In the early history of Nigeria nation, religion was a veritable tool for peace and development. It had little or no influence in politics, but had strong link with the educational and other social infrastructural developments of the country. But today religion and religious practitioners have adopted a policy of divide and rule. Religion was before now noted for its moral impact on the behavioural pattern of Nigerians, but today that seems to have been thrown to the mud.

Another area of concern is the high level of corruption. Nigeria and Nigerians have been branded as corrupt by international organizations and foreign countries. Nigeria is graded highly in the corruption indices worldwide. Corruption has eaten so deep into the fabric of the Nigerian society that the young and old, male and female as well as religious and atheist are all involve. According to Roland Okayi Ipuole (2016),

In recent time, stories about corruption dominate political and symbolic discourse in Nigeria. It is now considered as a normal way of life, especially perpetrated by those in government positions to amass illegal wealth. Corruption has penetrated the warp and woof of the Nigerian society. Cases of corruption occurs sometime between the boss and his messenger, the police officer and the recruit, the classroom teacher and his student, politician and voter, the judge and the lawyer, the pastor and his parishioner - none can remain untainted by this stigma.

The above statement shows that Government officials at all levels, market men and women, religious leaders and members are not left out. It exists in the holiest and profane places in the society. It involves money and materials, in exchange of goods and services, in economics, politics, relationships and other social facets of our society.

There is also clear evidence of moral decay in the Nigerian society. In relation to the issues of right and wrong and how people should behave, what is generally accepted no longer rules; goodness and decency appear to have been thrown to the dogs. The homes and religious institutions have relinquished their role of giving guidance on how to behave decently and honourably in society. The young no longer respect the adults and children give no honour to parents. Our policy makers, implementers and leaders ignore the common moral imperatives. Things that ought to be done because it is right, regardless of opposition or difficulty are ignored or rather the reverse becomes the case. Politics in Nigeria has become arena for immorality, fraud, idolatry and altar for bloodshed, therefore making politics a dirty game.

In the Nigeria political life the story is not different. Elections are won and lost not through the ballot box but on how much one is able to pay or who your political godfather is. Positions are not contested for but bought by wealthy individuals. The policy of "national character" no longer counts. Tribalism, ethnicity, nepotism, favouritism and "man-know-man" become the order of the day.

The above narrated state of affairs in the economic, political, social and religious spheres demands investigation hence this research. The need to find solution to this challenging situation that has negatively affected the Nigeria commonwealth becomes paramount in the minds of scholars.

\section{Theoretical Framework}


The researcher has decided to align this work with "The Rational Choice Theory." This theory was one of the intellectual influences that helped shape the development of other theories such as exchange theory, especially its tendency to assume a rational actor. The contemporary exchange and rational choice theories are far from conterminous. One fundamental difference is that while rational choice theorists focus on individual decision making, the basic unit of analysis to the exchange theorists is the social relationship (Ritzer 1996:400). According to Levi, the Rational Choice Theory originates from Karl Marx. The basic principles of this theory are derived from neoclassical economics (Levi et al 1990). Ritzer (1996) explains further,

It's (the theory) focus is on actors. Actors are seen as being purposive, or as having intentionality. That is, actors have ends or goals toward which their actions are aimed. Actors are also seen as having preferences (or values, utilities). Rational choice theory is unconcerned with what these preferences, or their sources, are. Of importance is the fact that actions are undertaken to achieve objectives that consistent with an actor's preference hierarchy.

This theory is economic related. According to Roemer (1986), it "is a technique developed by neoclassical economics", which is one of the approaches widely used throughout the social sciences. Although this theory draws from this class of economics, it is different, in the sense that it retains an interest in collective action for changing society and accepts the idea that capitalism is an unjust system (Ritzer 1996: 317). Despite the criticisms raised by scholars that "actors are rational and they seek to maximise their gains", this theory permits the analyst to go beyond the rational choices of a single actor and to deal with the interdependence of the decisions and actions of a number of actors. This theory is similar to "game theory" using the same principles in resolving social issues. Elston (n.d) (identifies three interdependences among actors involved in a game. "First, the reward for each actor depends on the choices made by all actors. Second, the reward for each actor depends on the reward for all. Finally, the choice made by each actor depends on the choices made by all."

Relating this theory to the topic of this research is to emphasize the need for actors in a society to, firstly that human beings are rational being and that two good heads are better than one. In the game of football, there are eleven players on the pitch, all working together to achieve the goal of winning the match. The goal may finally be scored by a player but without the cooperation of other players the scorer would not have scored the goal. And at the end it is the team that is rewarded and not just the goal scorer. Therefore for the purpose of rebuilding the Nigeria Commonwealth, there is need for all sectors of our society to be given opportunity to make rational contributions to reshape the country. That is why Elston's summary that each actor gets a reward based on the choices made by all actors, the benefit is equal to all, and therefore our choice as a nation should be significantly collective, for the good of all Nigerians.

\section{The Nigeria Commonwealth}

To examine here is the coming together of the various units - tribes, regions, and people to form a federated states. This is an official designation of the federated state and is often used to refer to the federal government as opposed to the state government. Nigeria is a commonwealth, with over one hundred and seventy million people that belong to many different ethnic groups. Nigeria has a federal form of government and is divided into thirty-six (36) states and the federal capital territory. By its official name, "The Federal Republic of Nigeria" it can be certain that Nigeria is a commonwealth.

According to Robert Stock (2009), the long period of colonial rule was under pressure by agitation for independence. Britain finally in 1947 responded "to the agitation by introducing a 
new constitution that divided Nigeria into 3 regions Northern, Eastern and Western each with own legislative Assemblies and were overseen by a weak federal government." However, Stock (2009) continues,

The constitution failed and was abrogated in 1949, and was followed by other constitutions in 1951 and 1954, each of which had contended with powerful ethnic forces. The Northern Peoples' Congress argued that northerners, who made up half of Nigeria population, should have a large representation in any federal legislature. The NPC was especially concerned about respect for Islam and the economic dominance of the south. The Western based Action Group also wanted autonomy, they feared that their profitable western cocoa industries would be tapped to subsidize less wealthy areas. In the poorer east, the National Council for Nigeria and the Cameroons wanted a powerful central government and a redistribution of wealth - the very things feared by the Action Group. The eventual compromise was the 1954 constitution which made Nigeria a Federation of three regions corresponding to the major ethnic groups - here power was more evenly split between the regional governments and the central government.

This brief review of the history of Nigeria has proven that the country is a commonwealth of people united by strong but elastic link. However, this coming together of various cultures also posed major challenges to nation building. Ethnic strife has plagued Nigeria since it gained independence from Britain in 1960. Despite the achievement of independence in 1960, it has since been plagued by problems, ranging from unequal distribution of wealth to ineffective, often corrupt government. The military ruled for over 20 years before handing over to the democratically elected government, these governments seem not to find solution to the economic, political and social problems of Nigeria (Irek \& Charles 2015; Adora \& Irek 2015; Irek 2018). It has therefore become necessary for solution to be sought elsewhere, hence the examination of the Confucius ethos in this article.

\section{The Confucius Ethos}

There is need to introduce the person - Confucius. According to Fisher (2008), his (Confucius) name was K'ung; the Chinese government honoured him as K'ung Fu-izu (Master $K^{\prime}$ 'ung) and called his teaching Juchiao (the teaching of the scholars). Confucius was the founder of Confucianism, a religion mostly found in the eastern part of the world (India and China). Confucius sought an understanding of society and authority that would be practical and it took him half his life to find it. He is quoted of saying about himself, "At 15 I took to learning, at 30 to standing firm, at $40 \mathrm{I}$ cease to doubt, at $50 \mathrm{I}$ knew the will of heaven, at $60 \mathrm{my}$ ear understood, at 70 I did what I desired and broke no rule" (Bowker 2007:175). He worked for the rule of $\mathrm{Lu}$ (a state in East China), but his ideas were not being put into practice, so he spent 13 years (477-484) travelling, looking for some ruler who would implement what he was advising. He found no takers, and returned to his home, teaching his followers and writing poetry and music (Bowker 2007:175).

The Confucius religious philosophy is based on the ancient Chinese beliefs in the Lord on high, the mandate of heaven, ancestor worship, spirits, and the efficacy of rituals. Confucius developed from these roots a school of thought that emphasizes the cultivation of moral virtues and the interaction between human rulers and heaven, with political involvement as the way to transforming the world (Fisher 2008:202). The primary concern of Confucius was with the humans and with the fundamental principles of humanity. Confucius believed that these principles were the root of social relationships, the foundation of the stability, peace and prosperity of the state, the family and individuals. According to Munro (1985), he developed 
his ethics around two central theses: that goodness can be taught and learned, and that society can only be in harmony and at peace under the guidance of wisdom. He further developed a system of concepts to expound the central theses. Of these concepts four became the underlying ideas of the Confucian tradition, namely, the Way (dao), ritual propriety (li), humane-ness (ren) and virtue $(d e)$, and later became the backbone of the ideological structure of a Confucian state. Devoting himself wholeheartedly to solving human problems, Confucius propagated the values of education, virtue and self-cultivation (Munro 1985:98).

According to Bowker (2007), the aim of Confucius was to bring into effect the will of Tian (the Divine, the creator who lives within it to maintain order) in the creation of a well ordered society. He derived from his teaching what he described as "the Three guiding Principles" (san pang) and the Five Enduring Regulations (wu chang) as the non-negotiable foundation of every life and society.

The three principles taught by Confucius

- Attitude of Obedience

This obedience by the subject is to the ruler at all levels. It is a commitment to the importance of a stable society, which can only be achieved by a serious knowledge of the past and it ways, in order to create people who learn how to live lives of humane goodness in relation to others.

- An attitude of $L i$

There are two levels of $L i$, the outer and the inner. The outer $L i$ is made up of the rites, ceremonies, manners and customs that bind humans to each other in a single community. The inner Li consists of the disposition to enter into all this with determination and goodwill (Bowker 2007:175).

- The quality of humane goodness. This is called Ren or Jen in Chinese language. This is the virtue of living generously moral and benevolent life. Those who live such lives are people who do their best for others and who are completely serene and at ease even when they themselves are overtaken by misfortune. Those who desire such virtue could learn it - partly by education, and partly by practice in the world. This attitude is summed up in the word $\mathrm{Li}$.

\section{The Teachings of Confucius}

The book of Mengzi or Mencius, the teachings of Confucius has it that Tian produces in humans four potentials which, if they are pursued and cultivated through education and practice, lead to lives in which the four great virtues are expressed. They are Ren and $L i$; Yi (the right disposition and action); and Zhi (insight or wisdom). These help to establish a just and compassionate society, and bring profound satisfaction to those who acquire and practise them (Bowker 2007:175). following:

Some of the specific teachings that directly affect the focus of this work include the

\section{On Government principles}

Confucius advocated a principle of governance that would ensure equity in government administration (Uduigwomen \& Edet et al., 2004). Two of his fundamental principles were revolutionary in the Chinese Culture of the time. They are (i) that those who govern should be 
chosen not on the basis of heredity, but on demonstrable characteristics of virtue and ability. (ii) that the true end of government is the total welfare and happiness of the people (Nigosian 1990:375).

In line with these principles Confucius maintained that the state should be a totally cooperative enterprise. Furthermore, that the right to govern depended on the individual rulers' moral character and ability to make his subjects happy.

Good government could only be established, by governors schooled in virtue and cultivated in character as well as in competence. According to Nigosian (1990), "The essence of Confucius doctrine was the negation of punishment and rigid law in favour of a positive example of virtue based on $L i$, or proper conduct exemplified by the criterion of Shu (reciprocity), that is the capacity to deal with others as we would have them deal with us."

Confucius did not advocate revolution, but he challenged established principles of government based on feudal states parcelled out like private properties among those wealthy or ruthless enough to exercise the power of life and death over those they ruled (Nigosian 1990:375). Confucius disparaged warfare as a solution to any problem, he rather pleaded for measures to mitigate the severity of punishment for even minor infractions of the law. He challenged the very foundations of the authoritarian government by insisting on the right of all individuals to make basic decisions for themselves, and he did what he could to mitigate the monopoly on education that the aristocracy enjoyed by accepting the poorest students provided that they were intelligent, hardworking and unpretentious (Nigosian 1990:376).

\section{The Superior Man}

The principle of "The Superior Man" was taught by Confucius. Based on his teachings, the characteristics that distinguished the superior man (literally prince-son) from the inferior man are qualities such as $l i$ (the code of moral, social conduct), jen (virtue, compassion, human heartedness, love), $y i$ (righteousness), and te (virtue). The sacred book of Confucianism (Analects) states that, "The superior man is concerned with virtue, the inferior man with land; the superior man understands what is right, the inferior man what is profitable" (Analects IV.11). It is acknowledged that individuals differ in inherent virtues and abilities, but Confucius believed that an appropriate education could nurture and cultivate the inherent moral characteristics that are prerequisites for the creation of the superior man (Nigosian 1990:376).

This principle applied in practical terms to other sectors of human existence produces acceptable moral and social conduct that affects every contact with fellow beings. Extending this principle to society, Confucius urged that a senior friend helps a junior friend and a junior friend respect his senior, and that a ruler acts beneficently to his subjects and the subjects obey their ruler.

Application of Confucius Ethos to Rebuild Nigeria Commonwealth

\section{a. Political System}

The political system in Nigeria needs to be revisited. Confucius saw the Chinese system of his time and concluded that there was need for it to be revisited. He saw in the Chinese system oppression, corruption and other vices that does not help improve the welfare of the people.

b. Resource Sharing

One of the challenging things in Nigeria political scene today is the issue of resource sharing. The country is witnessing increase in the number of indigenes of resource infested areas agitations for greater or better sharing of the resources that accrue from their communities. The reason is that the resources are not equitably distributed and the 
communities where these resources are gotten are not developed. Such a scenario demands the application of Confucius principle of "the Superior Man." This principle expects the host communities to be treated with compassion, love and human heartedness by ensuring that they benefit also from the resources that accrue from their land. The managers of these resources should be people who are morally sound and virtuous.

c. Education

Confucius taught that an appropriate education was capable of nurturing and cultivating the inherent moral characteristics that are requirement for the creation of men and women of sound moral integrity. If Nigerians should acquire such education and are willing to apply same in practical terms to the various sector of human existence it will in turn produce acceptable moral and social conduct that will affect every contact and dealings with fellow human being. Such attitude will reduce corruption, violence, hatred and encourage peaceful co-existence and development.

d. Social Order

The teaching of Confucius was perhaps rather less to do with religion in a conventional sense and more about the way in which he felt human beings should behave in day-to-day life and in which they should relate to their fellow human beings. He wanted people to be kind towards others and to display a considerate politeness in all their dealings with other people. He hoped that human beings would act sensibly with careful forethought and that they would have a sense of their obligations to others. Confucius hoped to persuade the ruler of his time that these principles were worthwhile and could be incorporated into a system of government. He probably envisaged these principles would one day become the moral basis of a political system (Oliver 2001:23). This is what is needed in Nigeria. Because this kind of principle is lacking, the Nigerian Government is spending so much money in fighting corruption, hate speech and criminality. These resources could have been ploughed into improving education and infrastructure in the country. Nigeria needs revival in her social environment. When this idea imbibe as it was accepted in China and the principles of Confucianism became the basis of social and political organization in that country, the objective of the founding fathers of our commonwealth will be realised.

Again, in Confucianism humans are seen as social beings. We can agree that in this human centred philosophy, man cannot exist alone; all actions must be in a form of interaction between man and man. This means that every action is focused towards improving man and his environment. It is devoid of selfishness and pride, tribalism and sectionalism, religiosity and spirituality. When each person observes his or her place in society and fulfils the required obligations and duties there is bound to be tranquillity, unity and progress in the commonwealth. Morality must consist of human-heartedness, righteousness and behaving according to the rules of propriety.

e. Self-Cultivation

Although relationships, roles and duties are necessary, they are anchored and based on individuals' virtue. Although virtue is received from heaven, it must be constantly cultivated to realize its true nature (Munro 1985:92). Confucius, in line with this noted that although "Heaven is the author of the Virtue in me", like a polished jade one must realise the virtue through constant self-cultivation (Munro 1985:92).

This means that a person can effectively realize his/her virtue through self-cultivation. Selfcultivation involves examining oneself from within and learning from others. Confucius explains that: when you meet someone better than yourself, turn your thoughts to becoming his equal. When you meet someone not as good as you are, look within and examine your own self" (Munro 93). Self-cultivation therefore requires constant self-examination. When 
this is done then, the well-being of others will be paramount for ones' well-being is to be secure. This is what Nigerians at all level need to do to sustain our commonwealth.

\section{CONCLUSION}

A lot could be learned from the ethos of Confucius that could help Nigeria rebuild here commonwealth. A total re-orientation is needed in Nigeria. Religious ethos such as presented to us from the Confucianism and others such as Christianity should be revisited and applied to strengthen the Nigeria commonwealth. With the closed examination of the Confucius ethos which this study has afforded the researcher, one is confident that religion can play a pivotal role in championing the campaign to evolve a more just, more equitable and a fairer resource control or a more acceptable restructuring formula that would not put any section of the country in a position of advantage over other parts. Certainly the lessons and teachings of Confucius can be appropriated by Nigerians in the quest to build a more egalitarian society that all citizens can be proud of and beneficial to the generations to come.

\section{REFERENCES}

Adora, C. U., \& Irek, N. E. (2015). Interrogating the Indifferences in the Application of Statistical Techniques In Theatre Scholarship. Nduñòde 15(1).

Alumuna, S., Ofoegbu, R. C., \& Edet, A. S. (2017). Militancy and Kidnapping in the Niger Delta Region of Nigeria; A Recap. Elixir Social Studies, 112, 49425-49434.

Bowker, J. (2007). Beliefs that Changed the World. London: Quercus Publishing.

Edet, A. (2017). Crime Control And Policing The Nation States; The Nigerian Police In Focus. International Journal of Social Sciences and Humanities Reviews, 7(2), 97-102.

Elston, J. (1982). "Marxism, Functionalism and Game Theory: The Case for

Eyo, E., \& Ogar, J. N. (2014). The Socratic "Man know thyself" and the problem of personal identity. Sophia: An African Journal of Philosophy, 15(1), 69-73.

Fisher, Mary Pat. (2008). Living Religions. New Jersey: Pearson Education.

Ikegbu, E. A., Ogar, J. N., \& Inyang, J. O. (2009). Nigeria's ethnic diversity and its proneness to conflict and violence. Ndunode: Calabar Journals of the Humanities, 8, 109-182.

Ipuole, Roland Okayi. (2016). "Corruption and Related Offences in Nigeria: Perspectives on Fraud, Obstruction of Justice and Violation of Due Process." Ed. Uti Egbai and Emeka C. Ekeke. Anti-Corruption Studies Vol.1. Calabar: Centre for General Studies and Communication Skills. 18-42.

Irek, N. E. (2018). Advertising as an Effective Promotional Tool for Theatre Marketing in Nigeria. Nsukka Ikenga International Journal of Institute of African Studies, 18(1).

Irek, N. E., \& Charles, E. (2015). Theatre Practice in Nigeria: Surveying the Past and Present. Ifok Journal of Interdisciplinary Studies, 2(1).

Methodological Individualism.” Theory and Society 11(4), 453-482.

Microsoft Corporation, 2008.

Munro, D. J. (1985). Individualism and Holism: Studies in Confucianism and Taoist Values. Michigan: Michigan UP. 
Nigosian, S. A. (1990).World Faiths. New York: St. Martin's.

Ritzer, G. (1996). Sociological Theory. Maryland: McGraw Hill.

Roemer, J. (1986). "Rational Choice' Marxism: Some issues of Method and Substance." J. Roemer (ed.). Analytical Marxism. Cambridge: Cambridge UP, 1986b, 191-201.

Stock, R. (2008). "Nigeria." Microsoft ${ }^{\circledR}$ Encarta ${ }^{\circledR} 2009$ [DVD]. Redmond, WA:

Streng, F. J. (1976). Understanding Religious Life. Belmont: Wadsworth Publishing.

The Mencius. (1960) Trans. by B. Watson, in Sources of Chinese Tradition, Comp. by

Twiss, S. B. (2011). "Confucian Contributions to the Universal Declaration of Human Rights: A Historical and Philosophical Perspective." Ed. Sharma. Arvind. The World's Religions: A Contemporary Reader. Minneapolis: Fortress Press, 102-114.

Uduigwomen, A. F., \& Edet, M. I. (2004). The primacy of the family in the philosophies of Confucius and Aristotle, and in African philosophy: A comparative analysis. Sophia: An African Journal of Philosophy, 7(1), 83-89.

W. T. de Bary, Wing-tsit Chan, and N. Watson. New York: Columbia University Press. 10501060.

Yinger, J. M. (1970).The Scientific Study of Religion. New York: MacMillan Publishing. 